Tropical Journal of Pharmaceutical Research October 2015; 14 (10): 1787-1795

ISSN: $1596-5996$ (print); 1596-9827 (electronic)

(C) Pharmacotherapy Group, Faculty of Pharmacy, University of Benin, Benin City, 300001 Nigeria.

All rights reserved.

Available online at http://www.tjpr.org

Original Research Article

http://dx.doi.org/10.4314/tjpr.v14i10.8

\title{
Antiproliferative Activity of Some Medicinal Plants on Human Breast and Hepatocellular Carcinoma Cell Lines and their Phenolic Contents
}

\author{
Fatma Pehlivan Karakas ${ }^{1}$, Arzu Birinci Yildirim', Recep Bayram ${ }^{3}$, Muhsine Z \\ Yavuz $^{3}$, Akcahan Gepdiremen ${ }^{3}$ and Arzu Ucar Turker ${ }^{2 \star}$ \\ ${ }^{1}$ Department of Field Crops, Faculty of Agriculture and Natural Sciences, ${ }^{2}$ Department of Biology, Faculty of Arts and Sciences, \\ ${ }^{3}$ Department of Pharmacology, Faculty of Medicine, Abant Izzet Baysal University, Bolu, Turkey \\ *For correspondence: Email: turker_a@ibu.edu.tr; Tel: +90 37425412 38; Fax: +90 3742534642
}

Received: 14 May 2015

Revised accepted: 5 September 2015

\begin{abstract}
Purpose: To determine the phenolic composition and antiproliferative activity of 16 different extracts (hexane, dichloromethane, methanol and water) obtained from Bellis perennis, Convolvulus galaticus, Trifolium pannonicum and Lysimachia vulgaris on human breast cancer (MCF-7) and human hepatocellular carcinoma (HepG2/C3A) cell lines.

Methods: The aerial parts of the plants were successively extracted with hexane, dichloromethane, methanol and water using a Soxhlet apparatus. The phenolic content of the plants were determined by plants by high performance liquid chromatography (HPLC) while their antiproliferative activity was evaluated by 3-(4,5-dimethylthiazol-2-yl)-2,5-diphenyl-tetrazolium bromide, a yellow tetrazole (MTT) assay.

Results: Among the tested extracts, the methanol extract of B. perennis showed the best antiproliferative activity against MCF-7 cell line with $1 C_{50}$ (inhibiting $50 \%$ of cell growth) value of $71.6 \mu \mathrm{g} / \mathrm{mL}$. Furthermore, the dichloromethane extract of $C$. galaticus showed the best anti-proliferative activity against HepG2/C3A cell line with $1 C_{50}$ of $57.3 \mu \mathrm{g} / \mathrm{mL}$. The HPLC data for the plant extracts showed the presence of the following phenolic compounds: gallic acid monohydrate, caffeic acid, rutin hydrate, Iuteolin-7-O- $\beta-D$ glucoside, kaempferol, myricetin, quercetin, coumarin and apigenin.

Conclusion: The findings of this study indicate that there is some justification for the use of B. perennis and C. galaticus as traditional anticancer medicinal herbs.
\end{abstract}

Keywords: Bellis perennis, Convolvulus galaticus, Trifolium pannonicum subsp. elongatum, Lysimachia vulgaris, MCF-7, HepG2/C3A, Phenolics, Breast cancer, Antiproliferative

\footnotetext{
Tropical Journal of Pharmaceutical Research is indexed by Science Citation Index (SciSearch), Scopus, International Pharmaceutical Abstract, Chemical Abstracts, Embase, Index Copernicus, EBSCO, African Index Medicus, JournalSeek, Journal Citation Reports/Science Edition, Directory of Open Access Journals (DOAJ), African Journal Online, Bioline International, Open-J-Gate and Pharmacy Abstracts
}

\section{INTRODUCTION}

Bellis perennis L. (common daisy) is a herbaceous perennial herb in the family Asteraceae [1]. Common daisy is known as a traditional wound herb [2,3] and it had been used for the treatment of bruises, broken bones [4], sore throat [5], headache [6], common cold [7], rheumatism, inflammation and infections of the upper respiratory tract in traditional medicine [8]. The main constituents are saponins $[9,10]$, essential oils [11], phenolics [12,13]. Antibacterial [11], antifungal [11,14], antioxidant [8,11], wound healing activity [2], anxiolytic properties [15], in vitro regeneration protocol [13], antitumor activity [16] and cytotoxic activity against HL-60 human promyelocytic leukemia cells [17] of $B$. perennis has also been investigated. 
Convolvulus galaticus Rostan ex Choisy (Grizzle bindweed) is an endemic, perennial herb in the family Convolvulaceae. Leaves and roots of $C$. galaticus have been used as chalogogue, laxative, antihelmintic and strongly purgative in traditional phytotherapy. Furthermore, its flowers are used in the relief of toothache $[18,19]$. Antibacterial [20,21], antitumor [21] and anticancer activities [22] of C. galaticus have been reported.

Trifolium pannonicum Jacq. subsp. elongatum (Willd.) Zoh. (Hungarian clover) is an endemic perennial plant belonging to Fabaceae family. Trifolium spp. has been used in folk medicine for the treatment of skin conditions [21]. $T$. pannonicum contains triterpene saponins in the seeds and flavonoid glycosides in the aerial parts [23]. Antibacterial [20,21] and antioxidant [23] activities of $T$. pannonicum have been reported.

Lysimachia vulgaris L. (yellow loosestrife) is a rhizomatous perennial herb in the family Primulaceae [24]. It has been used in the treatment of fever, ulcers, diarrhea, wounds and as an analgesic, expectorant and antiinflammatory agent since ancient time [19]. It is a convenient plant for phytopurification of wastewater [25]. It contains flavonoids, sterols, phenolic acids and tannins $[26,27]$. Podolak et al [27] reported that a benzoquinone pigment and triterpene saponosides from underground parts of yellow loosestrife had a cytotoxic activity in vitro against several cancer cell lines (human and mouse melanoma cells) and also inhibited the growth of Candida albicans strains.

The present study aims, for the first time to the best of our knowledge, to evaluate the antiproliferative properties of $B$. perennis, $C$. galaticus, T. pannonicum subsp. elongatum and L. vulgaris extracts (hexane, $\mathrm{DCM}, \mathrm{MeOH}$ and water) against human hepotocellular carcinoma (HepG2/C3A) cell and human breast cancer (MCF-7) cell lines.

\section{EXPERIMENTAL}

\section{Plant materials and preparation of extracts}

B. perennis, C. galaticus, and T. pannonicum Jacq. subsp. elongatum aerial parts were collected from Abant Izzet Baysal University Campus, Bolu/Turkey in 2013. L. vulgaris was collected from Abant Lake, Bolu/Turkey in 2013. Identification of the species was made by Arzu Ucar Turker using "Flora of Turkey and the East Aegean Islands" [24,28-29] and voucher specimens (Table 1) were deposited at the Abant Izzet Baysal University (AIBU) Herbarium, Bolu, Turkey.

The air-dried ( 1 week) powdered plant parts of $B$. perennis, $C$. galaticus, $T$. pannonicum and $L$. vulgaris were successively extracted with hexane (at $65-70{ }^{\circ} \mathrm{C}$ ), DCM (at $55-60{ }^{\circ} \mathrm{C}$ ), $\mathrm{MeOH}$ (at 60 ${ }^{\circ} \mathrm{C}$ ) and water (at $80^{\circ} \mathrm{C}$ ) to achieve extraction of both non-polar compounds to polar compounds, using a Soxhlet apparatus for $24 \mathrm{~h}$. The extracts were filtered and extraction solvents (hexane, $\mathrm{DCM}$ and $\mathrm{MeOH}$ ) were evaporated under low pressure at a temperature not higher than $45^{\circ} \mathrm{C}$ using rotary evaporator. Aqueous extracts were evaporated using a lyophilizator at $-65^{\circ} \mathrm{C}$. Plant materials, brief extraction procedure, designation of studied extracts and yields are shown in Table 1.

\section{Human cancer cell lines and culture conditions}

Human breast adenocarcinoma (MCF-7) and human hepatocellular carcinoma (HepG2/C3A) cell lines were obtained from the American Type Culture Collection (ATCC, Manassas, VA, USA). All cell lines were grown in Dulbecco's minimum essential medium (DMEM) with Earle's salts (Mediatech Cellgro, Herndon, USA). Culture medium was supplemented with $10 \%$ fetal bovine serum (FBS; Hyclone, Logan, USA), a solution of vitamins, sodium pyruvate and nonessential amino acids (all at 1:100 v/v dilution of supplied solutions), penicillin (100 I.U./mL) and streptomycin $(100 \mu \mathrm{g} / \mathrm{mL})$ (Mediatech Cellgro, VA). Cells were cultured at $37^{\circ} \mathrm{C}$ in a humidified environment containing $5 \% \mathrm{CO}_{2}$.

\section{Cell viability assay}

Exponentially growing cells were plated in 96well microplates (Costar, Corning Inc.) at a density of $10 \times 10^{3}$ cells per well in $100 \mu \mathrm{L}$ of culture medium and were allowed to adhere for $16 \mathrm{~h}$ before treatment. Increasing concentrations of each extract in DMSO (Sigma-Aldrich) were then added (100 $\mu \mathrm{L}$ per well) and the cells were incubated for $24 \mathrm{~h}$. The final concentration of DMSO in the culture medium was maintained at $0.5 \%(\mathrm{v} / \mathrm{v})$ to avoid solvent toxicity. Cytotoxicity was assessed using 3-(4,5-dimethylthiazol-2-yl)2,5-diphenyl-tetrazolium bromide, a yellow tetrazole (MTT) assay [30] on an automated 96well Multiskan FC micro plate photometer reader (Thermo Fisher Scientific Inc.) at $570 \mathrm{~nm}$. The proliferation test is based on the color reaction of mitochondrial dehydrogenase in living cells by MTT. The culture medium was removed and replaced with $90 \mu \mathrm{L}$ of fresh culture medium. Ten 
microlitres of sterile filtered MTT solution (5 $\mathrm{mg} / \mathrm{mL}$ ) in phosphate buffered saline (PBS, $\mathrm{pH}$ 7.4) were added to each well, reaching a final concentration of $0.5 \mathrm{mg} \mathrm{MTT/} \mathrm{ml}$ which was then incubated at $37{ }^{\circ} \mathrm{C}$ in $5 \% \mathrm{CO}_{2}$ for $4 \mathrm{~h}$. After $4 \mathrm{~h}$, $100 \mu \mathrm{l} /$ well of DMSO were added to all samples for dissolving the formazan that is the final product of MTT reaction and were allowed to incubate at $37{ }^{\circ} \mathrm{C}$, in a $5 \% \mathrm{CO}_{2}$ humidified incubator for a night. After incubation, absorbance of formazan was measured spectrophotometrically in a Multiskan FC microplate photometer reader at $570 \mathrm{~nm}$. Each experiment was carried out three times in triplicate. The relative cell viability (\%) relative to control wells containing cell culture medium without samples was calculated as:

Relative cell viability $=100 \times A 570 \mathrm{~nm}$ (sample) / A570 nm (control)

\section{HPLC analysis of phenolic compounds}

The DCM and methanolic extracts were analyzed using a HPLC system (VWR-Hitachi LaChrom Elite®) equipped with a Hitachi L-2455 DiodeArray Detector (DAD), Hitachi L-2130 Pump, Hitachi L-2200 Autosampler. Chromatographic separation was achieved using Hitachi column oven L-2300 and Venusil XBP C18 column (Bonna-Agela Technologies, particle size $5 \mu \mathrm{m}$, $4.6 \times 250 \mathrm{~mm}$ ). Flow rate was $1 \mathrm{ml} / \mathrm{min}$ with 25 ${ }^{\circ} \mathrm{C}$ oven and injection volume was $20 \mu \mathrm{L}$. All solvents were HPLC grade (Merck) and mobile phase was composed of solvent $A$ (acetronitrile) and solvent $B(0.1 \%$ acetic acid). A gradient elution was performed. Mobile phases and ultrapure water (SG Labostar) were filtered through a $0.45 \mu \mathrm{m}$ hydrophilic polypropylene membrane filter $(47 \mathrm{~mm}$ ) (Pall Corporation) prior to HPLC injection. Spectra data were recorded from to 200 to $400 \mathrm{~nm}$ during the entire run. The chromatograms were obtained at $280 \mathrm{~nm}$.

\section{Sample preparation for HPLC analysis}

Dried DCM and $\mathrm{MeOH}$ extracts $(100 \mathrm{mg})$ were dissolved in $1 \mathrm{ml}$ ACETRONITRILE. All standards (gallic acid monohydrate, caffeic acid, rutin hydrate, luteolin-7-O- $\beta-D$ glucoside, kaempferol, myricetin, quercetin, coumarin and apigenin) were prepared at $1 \mathrm{mg} / \mathrm{ml}$ in ACETRONITRILE and mixed together to make five different concentrations $(1,5,10,20,40,60$, 80 and $100 \mathrm{mg} / \mathrm{L})$ for the preparation of standard curve. All extracts and standards were filtered through a 0.2- $\mu \mathrm{m}$ GHP Acrodisc $(25 \mathrm{~mm}$ ) (Pall Corporation) into 2-mL HPLC vials. Procedures were repeated 3 times for each sample tested.

\section{Statistical analysis}

All data were analyzed by analysis of variance (ANOVA) with the last factor as a within subject or repeated design using SPSS version 15 (SPSS Inc., Chicago, IL, USA). Values were considered statistically significant at $p \leq 0.05$. The data are presented as mean \pm standard error (SE) after back transforming from ANOVA results.

\section{RESULTS}

The cytotoxic effects of the 16 crude extracts (hexane, dichloromethane, methanol and water) of B. perennis, C. galaticus, T. pannonicum and $L$. vulgaris at various concentrations were evaluated with in vitro cytotoxicity assay against MCF-7 and HepG2/C3A cell lines (Table 1). Percentage of the cell viability was measured by MTT assay (Figures 1 and 2). A plant extract is usually regarded as interesting for in vitro cytotoxic activity if $\mathrm{IC}_{50}<100 \mu \mathrm{g} / \mathrm{ml}$ [31].

The cytotoxic effects of all extracts against MCF7 and HepG2/C3A cells were shown in Table 1. Among the tested extracts, the methanolic extract of $B$. perennis showed the best antiproliferative activity against MCF-7 cell line with $I_{50}$ value of $71.6 \mu \mathrm{g} / \mathrm{mL}$. The aqueous extracts of $B$. perennis showed a moderate antiproliferative activity against MCF-7 cells, with the $\mathrm{IC}_{50}$ value of $147.6 \mu \mathrm{g} / \mathrm{mL}$. Meanwhile, DCM extract of $C$. galaticus showed also a moderate anti-proliferative activity against MCF-7 cell line, with the $\mathrm{IC}_{50}$ value of $172.4 \mu \mathrm{g} / \mathrm{mL}$ (Table 1 ).

Among the tested extracts, the DCM extract of $C$. galaticus showed the best anti-proliferative activity against HepG2/C3A cell line with $\mathrm{IC}_{50}$ value of $57.3 \mu \mathrm{g} / \mathrm{mL}$. Furthermore, $\mathrm{MeOH}$ extracts of $B$. perennis and $C$. galaticus showed high anti-proliferative activity against HepG2/C3A, with $I_{50}$ value of 73.9 and 75.4 $\mu \mathrm{g} / \mathrm{ml}$, respectively.

Other tested plant extracts did not show any antiproliferative activity against MCF-7 and HepG2/C3A cell lines at all concentrations tested (Table 1). The shape of dose-response curves indicated a significant inhibition of cell growth in a dose-dependent manner (Figures 1 and 2).

In the present study, quantification of the chosen phenolics in $B$. perennis, $C$. galaticus, $T$. pannonicum and $L$. vulgaris was performed using the HPLC technique. 
Table 1: In vitro anti-proliferative effect of studied plants on MCF-7 and HepG2/C3A cell lines

\begin{tabular}{|c|c|c|c|c|c|c|c|}
\hline \multirow[b]{2}{*}{ Family and Plants Species } & \multirow[b]{2}{*}{ Collection Number } & \multirow[b]{2}{*}{ Parts Used } & \multirow[b]{2}{*}{ Solvents } & \multirow[b]{2}{*}{ Designation } & \multirow[b]{2}{*}{ Yield $(\%) *$} & \multicolumn{2}{|c|}{$\mathrm{IC}_{50}(\mu \mathrm{g} / \mathrm{mL})$} \\
\hline & & & & & & MCF-7 & HepG2/C3A \\
\hline \multicolumn{8}{|l|}{ Asteraceae } \\
\hline \multirow{4}{*}{ Bellis perennis $\mathrm{L}$. } & \multirow{4}{*}{ AUT-1909 } & \multirow{4}{*}{ Flower } & Hexane & $\mathrm{BH}$ & 3.9 & $>200$ & $>200$ \\
\hline & & & DCM & BD & 2.5 & $>200$ & $184.7 \pm 1.2$ \\
\hline & & & $\mathrm{MeOH}$ & $\mathrm{BM}$ & 29.9 & $71.6 \pm 2.0$ & $73.9 \pm 3.0$ \\
\hline & & & Water & BW & 21.8 & $147.6 \pm 4.0$ & $154.2 \pm 0.7$ \\
\hline \multicolumn{8}{|l|}{ Convolvulaceae } \\
\hline \multirow{4}{*}{$\begin{array}{l}\text { Convolvulus galaticus Rostan ex } \\
\text { Choisy }\end{array}$} & \multirow{4}{*}{ AUT-2013 } & \multirow{4}{*}{ Aerial } & Hexane & $\mathrm{CH}$ & 1.7 & $>200$ & $166.9 \pm 0.2$ \\
\hline & & & $\mathrm{DCM}$ & $\mathrm{CD}$ & 5.2 & $172.4 \pm 0.5$ & $57.3 \pm 0.9$ \\
\hline & & & $\mathrm{MeOH}$ & $\mathrm{CM}$ & 11.7 & $>200$ & $75.4 \pm 1.5$ \\
\hline & & & Water & $\mathrm{CW}$ & 5.7 & $>200$ & $>200$ \\
\hline \multirow[t]{2}{*}{ Fabaceae } & \multirow{5}{*}{ AUT-2014 } & \multirow{5}{*}{ Aerial } & & & \multirow{5}{*}{$\begin{array}{c}0.9 \\
1.5 \\
7.1 \\
10.9\end{array}$} & & \\
\hline & & & Hexane & $\mathrm{TH}$ & & $>200$ & $>200$ \\
\hline \multirow{3}{*}{$\begin{array}{l}\text { Trifolium pannonicum Jacq. } \\
\text { subsp. elongatum (Willd.) Zohary }\end{array}$} & & & DCM & $\mathrm{TD}$ & & $>200$ & $>200$ \\
\hline & & & $\mathrm{MeOH}$ & TM & & $>200$ & $>200$ \\
\hline & & & Water & TW & & $>200$ & $>200$ \\
\hline \multirow[t]{2}{*}{ Primulaceae } & \multirow{5}{*}{ AUT-2008 } & \multirow{5}{*}{ Aerial } & & & \multirow{5}{*}{$\begin{array}{c}2.1 \\
3.4 \\
10.3 \\
2.9\end{array}$} & & \\
\hline & & & Hexane & LH & & $>200$ & $>200$ \\
\hline \multirow{3}{*}{ Lysimachia vulgaris $\mathrm{L}$. } & & & DCM & $\mathrm{LD}$ & & $>200$ & $>200$ \\
\hline & & & $\mathrm{MeOH}$ & $\mathrm{LM}$ & & $>200$ & $>200$ \\
\hline & & & Water & LW & & $>200$ & $>200$ \\
\hline
\end{tabular}

Note: Mean values ( \pm standard deviation) for triplicate assays. $1 C_{50}$ : Concentration of extract that cause $50 \%$ inhibition of cell proliferation.

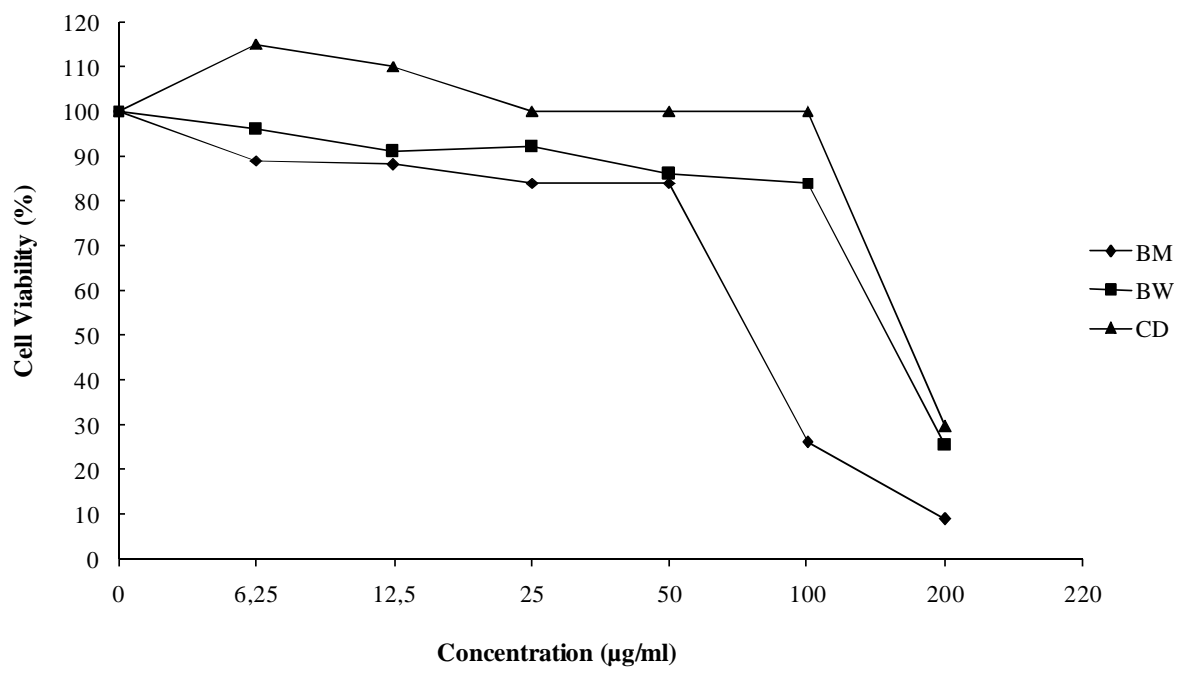

Fig. 1: Dose-response curves of the effect of BM, BW and CD extracts on cell growth in MCF-7 cells. Cells were treated with various concentrations $(6.25,12.5,25,50,100$ and $200 \mu \mathrm{g} / \mathrm{mL})$ of extracts, after $24 \mathrm{~h}$ of exposure. Antiproliferative effects were measured by MTT assay. Results were expressed as mean \pm SD $(n=3)$ 


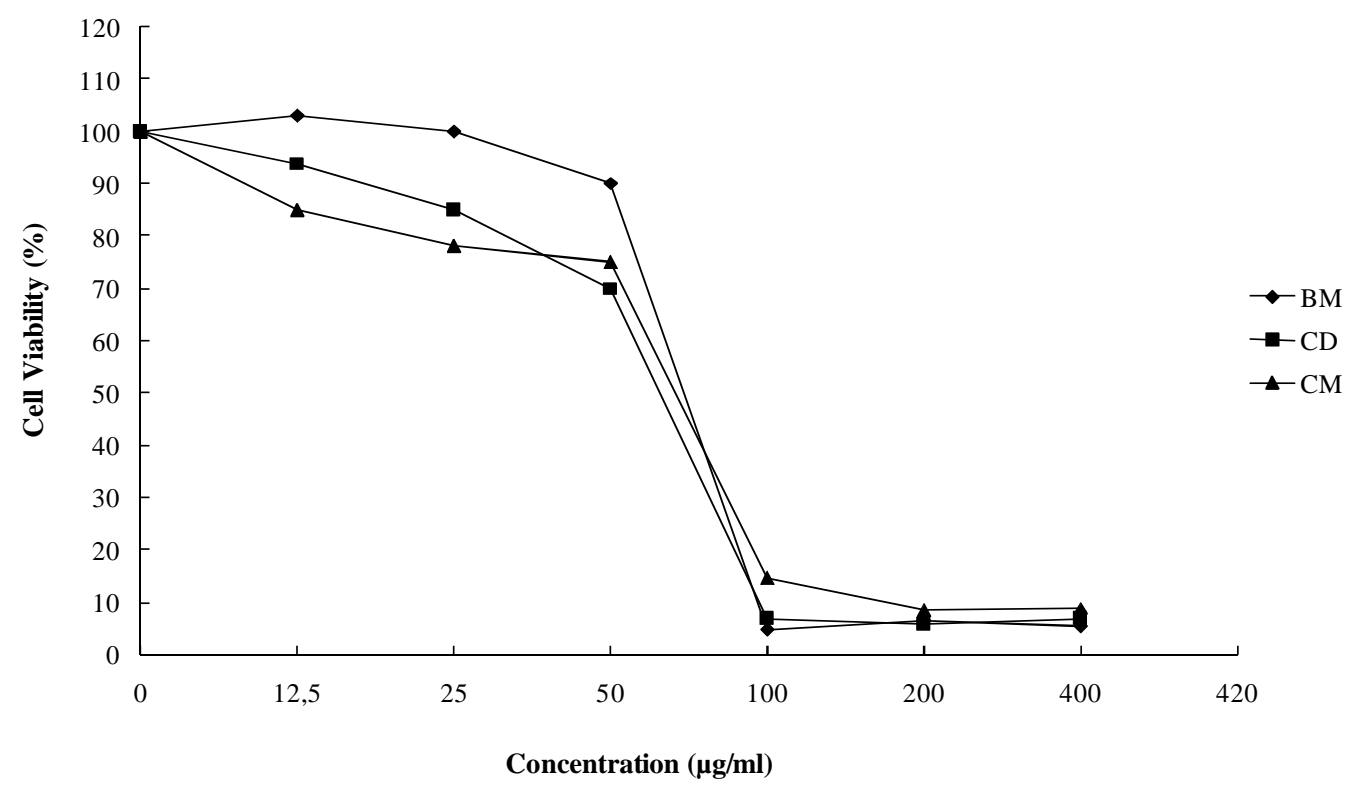

Fig. 2: Dose-response curves of the effects of BM, CD and CM extracts on cell growth in HepG2/C3A cells. Cells were treated with various concentrations $(12.5,25,50,100,200$ and $400 \mu \mathrm{g} / \mathrm{mL})$ of extracts, after $24 \mathrm{~h}$ of exposure. Antiproliferative effects were measured by MTT assay. Results were expressed as mean \pm SD for three independent determinations

The $\mathrm{MeOH}$ extract of $L$. vulgaris contained the highest total phenolic compounds $(40632.4 \mu \mathrm{g} / \mathrm{g}$ dry extract) (Table 2) while the DCM extract of $C$. galaticus contained the lowest total phenolic compounds (339.36 $\mu \mathrm{g} / \mathrm{g}$ dry extract). Considerable amounts of quercetin (12517.02 $\mu \mathrm{g} / \mathrm{g}$ dry extract) and apigenin $(512.54 \mu \mathrm{g} / \mathrm{g}$ dry extract) were found in $B$. perennis extracts. The most dominant were rutin hydrate and luteolin-7$O-\beta$-D glucoside in C. galaticus, $T$. pannonicum and $L$. vulgaris extracts (Table 2 ).

\section{DISCUSSION}

A high number of new natural drugs derived from plant secondary metabolites have been used in the treatment and/or prevention of cancer [32]. Since 1990, there has been a $22 \%$ increase in cancer incidence and mortality, with over 10 million new cases [32]. Important progress has been made in cancer chemotherapy, a considerable portion of which can be attributed to plant-derived drugs [32]. B. perennis has been used as a medicinal herb against cancer, breast cancer and uterine cancer [34]. In the literature, some saponins isolated from the root of $B$. perennis were found to be cytotoxic against only human promyelocytic leukemia (HL-60) cells [17]. However, no anticancer activity has been shown for flower extracts of $B$. perennis. Although there are some studies indicating the biological activities of $B$. perennis flower extracts, there is no study on the anticancer activity of this species. We therefore aimed to evaluate the anticancer activity of $B$. perennis by MTT assay on human breast adenocarcinoma (MCF-7) and human hepatocellular carcinoma (HepG2/C3A).

Generally, methanol extracts were more active on MCF-7 cell line. Methanol extracts of plant materials may contain active components such as tannins, polyphenols, polyacetylenes, flavonol, terpenoids, and flavonoids [35]. In the present study, TLC plates also showed that methanolic extracts contained more phenolic and saponin compounds qualitatively than other tested extracts of $B$. perennis (data not shown). Natural products have been shown to be an excellent and reliable source for the development of new drugs [36]. Saponins are well known compounds in B. perennis and they have anticancer activity against human promyelocytic leukemia (HL-60) cells [17]. In the present study, TLC results showed that $\mathrm{MeOH}$ extracts of flowers of $B$. perennis have more phenolic compounds and saponins than other extracts, (data not shown). Thus, in our present study, the high levels of anticancer activity of $\mathrm{MeOH}$ extracts of $B$. perennis may be attributed to this high saponin and phenolic contents. Extracts of B. perennis flowers have anticancer activity against the human breast adenocarcinoma (MCF-7) and human hepatocellular carcinoma (HepG2/C3A) cell lines. Altogether, these results support the traditional use of $B$. perennis in the treatment of cancer. 
Table 2: Content of selected phenolics in examined B. perennis, C. galaticus, T. pannonicum and L. vulgaris extracts. Values are means \pm SD $(\mathrm{n}=3$ )

$\begin{array}{ll}\text { STANDART COMPOUNDS } & \text { PLANT EXTRACTS }^{\mathrm{b}}(\mu \mathrm{\mu g} / \mathrm{g} \text { dry extract) }\end{array}$

\begin{tabular}{|c|c|c|c|c|c|c|c|c|c|c|}
\hline Name & Peak number ${ }^{a}$ & RT (min) & BD & BM & CD & $\mathbf{C M}$ & TD & $\mathbf{T M}$ & LD & $\mathbf{L M}$ \\
\hline Gallic acid monohydrate & 1 & 4.7 & $10.88 \pm 0.1$ & $11.64 \pm 0.05$ & $38.12 \pm 0.03$ & $133.01 \pm 0.01$ & $8.4 \pm 0.02$ & $80.5 \pm 0.04$ & $41.64 \pm 0.02$ & $139.0 \pm 0.1$ \\
\hline Caffeic acid & 2 & 10.65 & $47.06 \pm 0.07$ & $95.82 \pm 0.1$ & $34.0 \pm 0.01$ & $306.0 \pm 0.01$ & $4.0 \pm 0.01$ & $189.0 \pm 0.01$ & $83.0 \pm 0.02$ & $75.0 \pm 0.01$ \\
\hline Rutin hydrate & 3 & 11.92 & $244.62 \pm 0.01$ & $3239.12 \pm 0.02$ & $47.67 \pm 0.01$ & $2772.4 \pm 0.05$ & $6.73 \pm 0.01$ & $1285.4 \pm 0.5$ & $2613.0 \pm 0.4$ & $29024.0 \pm 0.7$ \\
\hline Luteolin-7-O- $\beta$-D glucoside & 4 & 12.52 & $63.64 \pm 0.07$ & - & $8.29 \pm 0.02$ & $1003.4 \pm 0.2$ & $20.4 \pm 0.02$ & $20959.4 \pm 0.9$ & $244.7 \pm 0.1$ & $8930.0 \pm 0.3$ \\
\hline Kaempferol & 5 & 12.7 & $147.8 \pm 0.1$ & $3241.94 \pm 0.01$ & $4.16 \pm 0.03$ & $521.1 \pm 0.1$ & $37.63 \pm 0.01$ & $73.5 \pm 0.01$ & $287.0 \pm 0.01$ & $437.0 \pm 0.02$ \\
\hline Myricetin & 6 & 14.1 & $67.42 \pm 0.05$ & $86.04 \pm 0.01$ & $68.21 \pm 0.01$ & $\leq 0.001$ & $\leq 0.001$ & $4680.1 \pm 0.7$ & $145.0 \pm 0.02$ & $605.0 \pm 0.1$ \\
\hline Quercetin & 7 & 15.76 & $340.52 \pm 0.02$ & $12517.02 \pm 0.01$ & $28.73 \pm 0.02$ & $329.5 \pm 0.02$ & $85.85 \pm 0.2$ & $3407.9 \pm 0.2$ & $1153.0 \pm 0.6$ & $958.0 \pm 0.05$ \\
\hline Coumarin & 8 & 16.68 & $1.34 \pm 0.01$ & - & $51.37 \pm 0.01$ & $91.0 \pm 0.1$ & $282.2 \pm 0.01$ & $\leq 0.001$ & $\leq 0.001$ & $\leq 0.001$ \\
\hline Apigenin & 9 & 17.05 & $512.54 \pm 0.02$ & $353.7 \pm 0.05$ & $58.8 \pm 0.5$ & $112.8 \pm 0.01$ & $\leq 0.001$ & $318.3 \pm 0.09$ & $\leq 0.001$ & $453.1 \pm 0.02$ \\
\hline Total Phenolics & & & 1435.82 & 19545.38 & 339.36 & 5136.0 & 445.06 & 30993.8 & 4566.54 & 40632.4 \\
\hline
\end{tabular}


Although Tokgun et al [22] reported the strongest anti-proliferative activity in methanolic extract of $C$. galaticus against MCF-7 cell line at low concentration $(0.32 \mathrm{mu} \mathrm{g} / \mathrm{mL})$, we found that the methanolic extract did not have a notable anti-proliferative activity against MCF-7 cell line. But DCM extract of $C$. galaticus had a moderate anti-proliferative activity against MCF-7 cell line in our study. The differences in these two studies may have arisen from plant extraction procedure. Furthermore, we are the first to report that DCM and methanol extracts of $C$. galaticus have antiproliferative activity against HepG2/C3A cell lines.

Podolak et al [27] showed the anticancer activity of $L$. vulgaris on human and mouse melanoma cells, however, we could not find the same activity against MCF-7 and HepG2/C3A cancer cells in our present study. The results of all studies indicated that different parts of plants had different levels of biological activity and phenolic compounds depending on the type of solvent used in the extraction procedure. The most important human diseases such as cancer, neurodegenerative and cardiovascular diseases are the result of free radicals.

Phenolics are that antioxidant compounds that are widely found in natural environments and inhibit free radical formation [37]. Because of this reason, we investigated the nine phenolic compositions (gallic acid monohydrate, caffeic acid, rutin hydrate, luteolin-7-O- $\beta-D$ glucoside, kaempferol, myricetin, quercetin, coumarin and apigenin) of tested extracts by HPLC analysis. The phenolic profiles of $C$. galaticus and $T$. pannonicum were detected for the first time and all tested standart phenolic compounds were found in both species. Toth et al [37] showed that polyphenol composition of three Lysimachia species. They similarly detected caffeic acid, chlorogenic acid, myricetin, isorhamnetin, quercetin and kaempferol in L. vulgaris. However, gallic acid, rutin hydrate, luteolin-7-O$\beta$-D glucoside and apigenin in $L$. vulgaris were demonstrated for the first time with our present study. It has been previously shown that phenolic constituents of $B$. perennis include flavonoids [13,38], anthocyanins [39] and phenolic acids (caffeic, ferulic, sinapic, p-coumaric, and salicylic acids) [40].

The following flavonoids were described in daisy flowers: quercetin, apigenin, kaempferol and isorhamnetin [38]. In the present study, some phenolic compounds such as coumarin, luteolin$7-O-\beta-D$ glucoside, myricetin and rutin hydrate were determined in flowers of $B$. perennis for the first time by HPLC analysis.

\section{CONCLUSION}

Our findings demonstrated that methanol extract of $B$. perennis flowers has anti-proliferative effect both on human breast cancer (MCF-7) and human hepatocellular carcinoma (HepG2/C3A) cancer cells. In addition, the methanolic and DCM extracts of C. galaticus have antiproliferative effects on HepG2/C3A cell line. With this study, B. perennis and C. galaticus gained scientific justification as anticancer medicinal herbs. Anticancer activities of $C$. galaticus against HepG2/C3A and $B$. perennis against MCF-7 and HepG2/C3A cancer cell lines were revealed for the first time. Furthermore, anticancer activities of aerial parts of $L$. vulgaris and $T$. pannonicum on human breast cancer (MCF-7) and human hepatocellular carcinoma (HepG2/C3A) were evaluated for the first time. Unfortunately, these plant extracts were not active to selected cancer cell lines in this study. Future studies should be focused on fractionation of the active plant extracts to identify active components with anticancer activity.

\section{ACKNOWLEDGEMENT}

This study was supported by the Abant Izzet Baysal University Research Foundation (no. BAP-2011.03.01.444). The authors also thank Assoc Prof Dr Hakan Turker for his technical support.

\section{REFERENCES}

1. Panda H. Handbook on Medicinal Herbs with Uses. India: Asia Pacific Business Press 2004.

2. Al-Douri NA, Al-Essa LY. A survey of plants used in Iraqi traditional medicine. J J Pharm Sci (2010); 3: 100108.

3. Karakaş FP, Karakas A, Boran Ç, Turker AU, Yalcın FN, Bilensoy $E$. The evaluation of topical administrations of Bellis perennis fractions on circular excision wound healing in Wistar albino rats. Pharm Biol 2012; 50 (8): 1031-1037.

4. Mitich LW. Engilish daisy (Bellis perennis L.). Weed Technol 1997; 11: 626-628.

5. Uysal I, Onar S, Karabacak E, Celik S. Ethnobotanical aspects of Kapıdag Peninsula (Turkey). Biol Diver Conserv 2010; 3: 15-22.

6. Uzun E, Sariyar G, Adsersen A, Karakoc B, Otük G, Oktayoglu E, Pirildar S. Traditional medicine in Sakarya province (Turkey) and antimicrobial activities of selected species. J Ethnopharmacol 2004; 95: 287-296.

7. Cakılcıoglu U, Sengun MT, Turkoglu I. An ethnobotanical survey of medicinal plants of Yazıkonak and Yurtbası 
districts of Elazığ province, Turkey. J Med Plant Res 2010; 4: 567-572.

8. Siatka $T$, Kasparova M. Seasonal variation in total phenolic and flavonoid contents and DPPH Scavenging activity of Bellis perennis L. flowers. Molecules 2010; 15: 9450-9461.

9. Morikawa T, Li X, Nishida E, Ito Y, Matsuda H, Nakamura S, Muraoka O, Yoshikawa M. Perennisosides I-VII, acylated triterpene saponins with antihyperlipidemic activities from the flowers of Bellis perennis. $J$ Nat Prod Res 2008; 71: 828-835.

10. Karakas FP, Şöhretoğlu D, Liptaj T, Stujber M, Turker $A$ $U$, Marak J, Çalış I, Yalçın FN. Isolation of an oleanane-type saponin active from Bellis perennis through antitumor bioassay-guided procedures. Pharm Biol 2014; 52: 951-955.

11. Kavalcioglu N, Acik L, Demirci F, Demirci B, Demir H Baser KHC. Biological activities of Bellis perennis volatiles and extracts. Nat Prod Commun 2010; 5: 147-150.

12. Gudej J, Nazaruk J. Flavonol glycosides from the flowers of Bellis perennis. Fitoterapia 2001; 72: 839-840.

13. Karakas FP, Turker AU. An efficient in vitro regeneration system for Bellis perennis L. and comparison of phenolic contents of field-grown and in vitro-grown leaves by LC-MS/MS. Ind Crop Prod 2013; 48: 162170.

14. Avato $P$, Vitali $C$, Mongelli $P$, Tava A. Antimicrobial activity of polyacetylenes from Bellis perennis and their synthetic derivatives. Planta Med 1997; 63: 503507.

15. Karakas FP, Karakas A, Coşkun H, Turker AU. Effects of common daisy (Bellis perennis L.) aqueous extracts on anxiety-like behaviour and spatial memory performance in wistar albino rats. Afr $J$ Pharm Pharmacol 2011; 5: 1378-1388.

16. Karakas FP, Turker AU, Yalcin F, Calıs I. Antitumor activities of some Bellis perennis $L$. fractions. 58th International congress and annual meeting of the society for medicinal plant and natural product research. Berlin, Germany, Planta Med 2010; 76 (12): 1261-1261.

17. Li W, Asada Y, Koike K, Nikaido T, Furuya T, Yoshikawa $T$. Bellisosides $A-F$, six novel acylated triterpenoid saponins from Bellis perennis (compositae). Tetrahedron 2005; 61: 2921-2929.

18. Grieve M. A Modern Herbal, vol 1. New York: Dover Publications 1982.

19. Baytop T. Therapy with Medicinal Plants in Turkey (Past and Present). Istanbul, Turkey:Nobel Medical Book house 1999.

20. Turker H, Yıldırım AB, Karakas FP. Antibacterial activities of extracts from someTurkish endemic plants on common fish pathogens. Turk J Biol 2009; 33: 73-78.

21. Turker AU, Koyluoglu H. Biological activities of some endemic plants in Turkey.Romanian Biotechnol. Letters 2012; 17: 6949-6961.
22. Tokgun O, Akca H, Mammadov R, Aykurt C, Deniz G. Convolvulus galaticus, Crocus antalyensis, and Lilium candidum extracts show their antitumor activity through induction of p53-mediated apoptosis on human breast cancer cell line MCF-7 cells. J Medicinal Food 2012; 15: 1000-1005.

23. Godevac D, Zdunic G, Savikin K, Vajs V, Menkovic N. Antioxidant activity of nine Fabaceae species growing in Serbia and Montenegro. Fitoterapia 2008; 79: 185187.

24. Davis PH. Flora of Turkey and the East Aegean Islands, vol. 6. Edinburgh University Press, 1978.

25. Borin M. Phytopurification u solutions for treatment of wastewater with plants. 195. Edagricole Press, Bologna, Italy, 2003.

26. Janik I, Janeczko Z, Sendra J, Burczyk J. Benzoquinone pigment from Lysimachia vulgaris. Fitoterapia 1994; 65 (5): 476.

27. Podolak I, Elas M, Cieszka K. In vitro antifungal and cytotoxic activity of Triterpene saponosides and quinoid pigments from Lysimachia vulgaris $L$. Phytother Res 1998; 12: 70-73.

28. Davis PH. Flora of Turkey and the east aegean islands. vol 3, Edinburgh University Press, 1970.

29. Davis PH. Flora of Turkey and the East Aegean Islands, vol 5. Edinburgh University Press, 1975

30. Mosmann T. Rapid colorimetric assay for cellular growth and survival: application toproliferation and cytotoxicity assays. J Immunol Meth 1983; 65: 55-63.

31. Boyd $\mathrm{MR}$. The $\mathrm{NCl}$ in vitro anticancer drug discovery screen: concept, implementation, and operation. In: Anticancer Drug Development Guide: Preclinical Screening, Clinical Trials, and Approval, (Ed. Teicher, B.A.), 23-42. Humana Press, Totowa, NJ, 1997.

32. Newman DJ, Cragg GM, Snader KM. Natural products as sources of new drugs over the period 1981-2002. J Nat Prod 2003; 66:1022-1037.

33. Parkin DM, Bray F, Ferlay J, Pisani P. Estimating the world cancer burden: Globocan 2000. Int J Cancer 2001; 94: 153-156.

34. Duke JA, Bogenschutz-Godwin MJ, DuCellier J, Duke PA. Handbook of Medicinal Plants, second ed. CRC Press, Boca Raton, FL, p. 273, 2002.

35. Samsam-Shariat SH. Qualitative and quantitative evaluation of the active constituents and control methods for medical plants. 23-30. Mani Publications, Isfahan, 1992

36. Newman DJ, Cragg GM. Natural products as sources of new drugs over the last 25 years.J Nat Prod 2007; 70: 461-477.

37. Toth A, Toth G, Kery A. Polyphenol composition and antioxidant capacity of three Lysimachia species. Nat Prod Commun 2014; 9: 1473-1478.

38. Nazaruk J, Gudej J. Qualitative and quantitative chromatographic investigation of flavonoids in Bellis perennis L. Acta Pol Pharm 2001; 58: 401-404. 
Karakas et al

39. Toki K, Saito N, Honda T. Three cyanidin 3glucuronylglucosides from red flowers of Bellis perennis. Phytochemistry 1991; 30: 3769-3771.
40. Grabias B, Dombrowicz E, Kalemba D, Swiatek L. Phenolic acids in flores bellidis and herba tropaeoli. Herba Pol 1995; 41: 111-114. 